\title{
PROSES ADMINISTRASI PADA BIDANG PENDIDIKAN SARANA DAN PRASARANA DI SEKOLAH
}

\author{
Resty Nurqomah \\ Email: 2010128220014@mhs.ulm.ac.id \\ Program Studi Pendidikan IPS Fakultas Keguruan dan Ilmu Pendidikan \\ Universitas Lambung Mangkurat \\ Banjarmasin
}

\begin{abstract}
Abstrak
Kedudukan bernilai Administrasi Sarana serta Prasarana di sekolah sangatlah perlu dicermati, sebab ketersediaan fasilitas atau sarana serta prasarana yang lumayan serta baik bisa mendukung kesuksesan suatu sekolah, dalam konteks ini Fasilitas serta Prasarana berpotensi buat mendukung kelancaran proses kegiatan pendidikan serta pembelajaran yang akan cocok dengan yang direncanakan. Tanpa terdapatnya fasilitas serta prasarana yang lumayan serta baik, mustahil tujuan yang ingin serta idamkan dalam sekolah bisa dicapai. Sekolah ataupun kantor pembelajaran merupakan lokasi langsungnya aktifitas berkait dengan tata usaha maupun administrasi pada butuhkan fasilitas serta pra-sarana yang baik. Supaya seluruh aktivitas, hubungan deng-an bekal sekolah bagus, juga bertabiat administrasi ataupun teknls operasi bisa jalankan deng-an bagus serta efesien, hingga penerapan ataupun pengelolaan fasilitas serta prasarana sekolah mesti dicoba sebaik mungkin.
\end{abstract}

Keywords: Administrasi, fasilitas, prasarana, pembelajaran, sekolah

\section{Pendahuluan}

Tersedianya fasilitas serta pra-sarana lumayan deng-an unggul bagus, memang perlu selalu di sekolah manapun da-lam selanggarakan kegiatan buat gapai sesuatu harapkan. Pada realitasnya tiap sekolah memerlukan ataupun membutuhkan ketersediaan fasilitas serta prasarana dengan lumayan serta layak, dengan tidak menutup tampaknya dalam kantor pembelajaran ataupun sekolah sangat memerlukan fasilitas serta prasarana ini. Sehingga perihal ini ialah topik utama dalam penataan artikel ini yang cocok dengan apa yang memuat pada judul artikel ialah Proses Administrasi pada Bidang Pendidikan Sarana dan Prasarana di Sekolah, di mana administrasi fasilitas serta prasarana pembelajaran merupakan keseluruhan dengan langsungnya ataupun tak langsungnya bisa mendukung jalan menuju pembelajaran buat menggapai tujuan yang di idamkan dalam pembelajaran itu sendiri. Pembelajaran ialah tolak ukur untuk suatu negeri apakah negeri tersebut maju dalam pola pikir ataupun tidak. Hingga dari itu pengelolaannya wajib dikelola secara baik serta benar, salah satu diantaranya yang sangat berarti merupakan administrasi fasilitas serta prasarana dalam bidang pembelajaran.

Dalam dunia pembelajaran fasilitas serta prasarana ialah keseluruhan dalam berarti tercapainya kualltas pendidikan yang berkualitas, baik mempengaruhi secara langsung ataupun tidak langsung. Ada pula tujuan dari pembuatan artikel ini merupakan sebab terbatasnya 
pengetahuan dari sebagian personal tata usaha ataupun personal yang lain dalam sekolah ataupun kantor pembelajaran tentang administrasi fasilitas serta prasarana pembelajaran, dan minimnya hasrat dari mereka buat mengenali serta memahaminya dengan baik. Dengan membagikan data untuk para pembaca tentang apa administrasi fasilitas serta prasarana pembelajaran yang sebaiknya dijalankan serta menambah pengetahuan pembaca mengenai administrasi fasilitas serta prasarana dalam pembelajaran, sebab masih banyak dari bermacam pihak dalam area sekolah itu yang belum paham mengenai administrasi fasilitas serta prasarana. Hingga dari itu penulis menyusun artikel ini dengan harapan bisa menaikkan pengetahuan mereka tentang Proses Administrasi pada Bidang Pendidikan Sarana dan Prasarana di Sekolah dan bisa mempraktikkannya serta memakai apa yang sudah mereka tahu itu dalam kehidupan tiap hari.

\section{Metode}

Metode yang dipergunakan dalam proses pengumpulan informasi, yang dicoba adalah memakai tata cara literatur, dokumentasi, mengenali bermacam masukan, dan data terkini dari internet. Tidak hanya itu, sumber informasi yang dicoba dalam mekanisme penulis adalah informasi sekunder. Informasi sekunder merupakan informasi yang diperoleh lewat pengumpulan informasi yang ada, dengan terdapat kaitannya dengan riset literal. Metode informasi dalam riset literal ini dicoba dengan memakai tata cara dokumentasi. Bagi Hamidi (2008) metode pengumpulan informasi buat dokumentasi ialah mengumpulkan informasi berbentuk data yang berasal dari catatan berarti (kepustakaan). Metode analisis informasi yang dipergunakan ialah metode menganalisis informasi riset, tercantum alat statlstik rele-van buat gunakan riset. Riset bertabiat kualitatlf, hingga analisis informasi digunakan metode menganalisis susunan kualitatlf. Penulis dari novel penataan kualitatif Denzin dan Lincoln memberi tahu jika penataan kualitatif ialah penataan gunakan altar alami, maksudnya penafsiran kejadian terjalin, serta dicoba mengaitkan bagai tata me-tode tersedia. Buat pengumpulan data dan informasi mengenakan penulusuran pustaka dan pencarian sumbersumber relevan melalui internet, dari media elektronik berupa buletin ataupun surat kabar dan dokumen yang lain. Sehabis segala hal diperoleh, setelah itu dicoba kajian isi terhadap totalitas, yang dimaksud disini sebagaimana pendapat Weber ialah metodologi penataan yang memakai seperangkat prosedur buat menarik kesimpulan dari sesuatu dokumen.

\section{Pembahasan}

Bagi karnus B. Indonesia fasilitas merupakan seluruh suatu yang bisa dipakai selaku perlengkapan dalam meraih maksud ataupun tujuan. Sebaliknya prasarana merupakan seluruh 
suatu yang menggambarkan tunjangan center menyeleggarakan sesuatu (upaya, pernbangunan,). Sebaliknya etirnologis fasilitas yakni perlengkapan langsungnya buat menggapai suatu pembelajaran, misal ruang, novel, taman pustaka, laboratorium serta sebagainya. Sebaliknya pra-sarana yaitu perlengkapan tak langsungnya buat menggapai suatu pembelajaran, misal: letak maupun lokasi, pembangunan sekolahan, tanah lapang berolahraga, duit, serta lainnya. Bagi rumusan Regu Penyusun Pedoman Pembakuan Media Pembelajaran Kementerian Pembelajaran serta Kebudayaan, mengartikan dengan Fasilitas pembelajaran merupakan seluruh sarana yang dibutuhkan pada berlangsungnya belajaran meng-ajar secara ber-gerak maupun tak ber-gerak hingga mencapai suatu pembelajaran bisa jalan deng-an nyaman, beraturan, efisien serta lainnya. Deng-an dernikian bisa membuat simpulan kalau Administrasi fasilitas serta pra-sarana pembelajaran merupakan seluruh keseluruhan langsungnya ataupun tak langsungnya mendukung jalan berlangsungnya pembelajaran buat menggapai suatu pembelajaran sendirinya.

Administrasi bidang pendidikan terdapat fasilitas serta prasarana yang merupakan segala berlangsungnya kegiatan terencana hingga berusaha sesuai rencana dan serius menggunakan binaan continue pada benda-benda pembelajaran supaya tetap siap pada saat digunakan berlangsungnya belajaran meng-ajar hingga efisien serta efek-tif menolong mencapai suatu pembelajaran sudah diresmikan di dalam sekolah. Dengan demikian administrasi pada bidang pendidikan, yakni melakukan usaha buat mengupayakan fasilitas serta perlengkapan peraga yang diperlukan pada proses pendidikan demi lancarnya serta tercapainya tujuan pembelajaran.

Fasilitas pembelajaran diklasifikasikan jadi 3 ragam, ialah:

1. Ditinjau ataupun dilihat dari habis tidaknya dipakai fasilitas pembelajaran yang terdapat 2 hal yakni:

a. Fasilitas pembelajaran yang habis dipakai merupakan seluruh bahan ataupun perlengkapan, jika gunakan dapat terkikis pada kurun re-latif pendek. Semacam: Kapur, bahan kimia serta lainnya.

b. Fasilitas pembelajaran awet pada kurun panjang merupakan totalitas materi ataupun perlengkapan bisa gunakan seterusnya serta pada kurun re-latif panjnag. Semacam: Sofa, rneja, papan untuk menulis serta lainnya.

2. Tinjauan darl ber-gerak tidak disaat gunakan, dengan dibagi menjadi 2 yakni:

a. Fasilitas pembelajaran yang bergerak merupakan fasilitas pembelajaran yang dapat digerakkan ataupun dipindah, di mana cocok secara pemenuhan pemakai, contohnya: lemari arsip sekolahan, bangku sekolahan, serta lainnya. 
b. Fasilitas pembelajaran tidak bergerak merupakan seluruh fasilitas pembelajaran yang tidak dapat ataupun relatif sangat susah buat dipindahkan, misalnya saluran dari Industri Wilayah Air Minum (PDAM).

3. Tinjauan darl hubungan berlangsungnya belajaran meng-ajar yang bisa bedakan jadi tiga ragam yakni:

a. Perlengkapan pelajaran,

b. Perlengkapan peraga, serta

c. Media pengajaran.

Ada pula Prasarana pembelajaran di sekolah dapat diklasifikasikan jadi 2 ragam, ialah:

1) Pra-sarana pembelajaran langsungnya gunakan buat berlangsungnya belajaran mengajarkan, semacam lokasi teori, lokasi taman pustaka, lokasi praktek keahlian, serta lokasi lab.

2) Pra-sarana sekolahan beraada tak gunakan buat berlangsung belajaran mengajarkan, namun langsungnya sangatlah mendukung terbentuknya berlangsung belajaran mengajarkan, misaln letak kantor, kantin sekolahan, tanah serta jalur mengarah sekolahan, karnar kecll, lokasi pendidik, lokasi kepala sekolah, serta letak parkiran transportasi.

Bagi (Sutjlpto, 1993) kegiatan administrasi pada fasilitas serta pra-sarana pembelajaran yakni:
A. Perencanaan,
B. Pengadaan,
C. Inventarisasi,
D. Penyaluran,
E. Pemanfaatan serta pemeliharaan,
F. Penghapusan, juga
G. Pengawasan fasilitas.

Serta pada pra-sarana pembelajaran, yang bisa dijabarkan pada hal berikut:

1. Perencanaan

Perencanaan fasilitas serta prasarana pembelajaran ialah sesuatu berlangsungnya menganalisis serta menetapkan pemenuhan dibutuhkan berlangsungnya pendidikan hingga muncul-lah sebutan pemenuhan dibutuhkan serta pemenuhan mendukung. Di mana berlangsungnya penyusunan rencana mesti dicoba secara teliti serta hati-hati, yang berkait pada ciri fasilitas serta pra-sarana diperlukan, jumlah, jenis serta kendala (untuk mendapat guna dapatkan), serta biaya. Perencanaan pengadaan peralatan pembelajaran di sekolah wajib dimulai menganalisis tipe yang pernah dilakukan pembelajaran progaram sekolahan. Bagi Sukarna selaku: 
a. Menampungnya seluruh usul-an adanya peralatan sekolahan mengajukan dari tiap kelompok kerjaan serta iventarisasi kurangan peralatan sekolahan.

b. Menyusunkan rancangan pemenuhan peralatan sekolahan buat kapan tentunya, misal buat 1 sernester ataupun 1 tahunan ajar.

c. Padukan rancangan pemenuhan sudah susunan peralatan ada sebelum-nya.

d. Padukan rancangan pemenuhan pendanaan ataupun budget sekolahan ada.

e. Padukan rancangan (catatan) pemenuhan peralatan ur-gen pendanaan ataupun budget ada hingga butuh adakan pilih memandang ska-la priorltas.

f. Menetapkan rancangan mengadakan diakhir.

2. Pengadaan

Pengadaan merupakan seluruh aktivitas menyediakan fasilitas serta pra-sarana buat mendukung penerapan penugasan. Sebab guna serta aktivitas, seperti pada tiap organisasi berbeda, hingga pengadaan fasilitas serta pra-sarana kantor pula takk senantiasa sarna antar kelompok 1 serta kelompok lainnya. Saat pengadaan fasilitas serta pra-sarana ter-sebut mesti dicoba rencana dulu. Hal butuh dicermati pada penyusunan rencana fasilitas serta prasarana kantor, yakni:

a. Pakai tata cara pengendalian fasilitas serta pra-sarana.

b. Menentukan tipe, kuantltas, serta mutu fasilitas serta prasarana yang diperlukan.

c. Menyesuaikan antar pemenuhan fasilitas serta pra-sarana bayaran ada.

d. Sajikan serta pakai fasilitas serta prasarana dalam aktivitas operasional.

e. Penyimpanan serta pemeliharaan fasilitas serta prasarana.

f. Kumpulkan serta kelola informasi fasilitas serta prasarana.

g. Penghapusan fasilitas serta pra-sarana menyesuaikan tata cara valid.

3. Inventaris

Mengadakan seluruh fasilitas serta pra-sarana kantor membutuhkan bayaran besar, dengan tercantum seluruh aktivitas kaitan deng-an pengendaliannya. Buat dibutuhkan aktivitas inventarisasi. Inventarisasi fasilitas serta pra-sarana biro merupakan seluruh aktivitas serta usaha buat mendapatkan informasi yang dibutuhkan mengenai fasilitas serta prasarana yang dipunyai. Secara pendek inventarisasi bisa dimaksud selaku pencatatan terhadap fasilitas serta pra-sarana. Inventarisasi dicoba tiap kelompok dapat aja beda, tetapi ada dasar seluruh dicoba deng-an tuju-an selaras. Di mana suatu inventarisasi fasilitas serta pra-sarana yakni:

a. Supaya perlengkapan tak gampang lenyap.

b. Terdapatnya fakta tulis pada aktivitas pengendalian benda hingga bisa pertanggungjawabkan. 

c. Mempermudah pada mencek benda.
d. Mempermudah pada mengawasi.
e. Mempermudah kala pengadaan aktivitas penghapusan benda.

4. Penyaluran

Penyaluran ialah aktivitas tersangkut memindah benda serta berkewajiban lembaga ataupun memegang 1 pada lembaga maupun memegang lainnya. Aktivitas penyaluran benda memenuhi 3:

a. Penataan Lokasi

Buat menjauhi borosnya bagian ataupun distribusi benda hingga menyeluruh serta balance pemenuhan memakai individu, hingga butuh susunan lokasi kuantltas serta frekuensl distribusiannya, hingga serius bisa mendukung aktivitas instrukslonal.

b. Pengiriman Benda

Mengirim benda center menyalurkan benda butuh mencermati sebagian perihal, seperti:

1) Metode pengiriman,

2) Pengemasan,

3) Pemuatan,

4) Pengangkutan serta

5) pembongkarang.

c. Penyerahan Benda

Dalam penyerahan benda hendaknya tidak diabaikan buat mengisi catatan penyerahan benda, pesan pengantaran, faktur, ciri penerima serahan benda, bayaran mengirimkan serta lainnya.

5. Pemanfaatan serta Pemeliharaan

Eksploitasi merupakan aktivitas yang selalu mengusahakan supaya benda ataupun bahan kantor senantiasa dalam kondisi baik ataupun siap buat dipakai. Di mana tujuan pemeliharaan fasilitas serta pra-sarana biro ini, antar:

a. Supaya benda tak gampang hancur sebab bakteri ataupun temperatur maupun cuaca.

b. Supaya benda tidak gampang lenyap.

c. Supaya benda tidak kadaluarsa.

d. Supaya benda tidak gampang susut.

e. Supaya fasilitas serta prasarana senantiasa dalam kondisi bersih.

6. Penghapusan

Penghapusan ialah sesuatu proses aktivitas yang bertujuan buat menghasilkan ataupun melenyapkan beberapa barang kepunyaan Negeri dari catatan inventaris negeri bersumber 
pada aturan UU. Jika bayaran rehabilitasl benda sangat banyak sedang energi pakai sangat pendek hingga benda baiknya tak pakaikan again serta keluarkan catatan inventaris. Guna dari pengendalian peralatan penghapusan memiliki makna:

a. Menghindari atau menghalangi rugi banyaknya, sebab diakibatkan:

1) Mengeluarkan terus menjadi banyak buat bayaran rawat serta revisi ataupun pemeliharaan terhadap benda yang terus menjadi kurang baik kondisinya.

2) Pemborosan bayaran buat pengamanan beberapa barang kelebihan ataupun benda lain yang sebab sebagian karena, tidak bisa gunakan.

b. Ringankan kewajiban tugas inventarisasi sebab banyak nya beberapa barang yang tinggal menurun.

7. Pengawasan

Segala aktivitas Administrasi Fasilitas serta Prasarana Pembelajaran tidak dapat jalan sendirinya without kendalikan serta awasi, maksudnya tiap aktivitas individu bakal monitoring tiap disaat pemimpin kelompok dan dicermati kerjasama 1 lainnya. Pengawasan tidak ialah sesuatu aturan keras serta hendak menghalangi lokasi bergerak tiap-tiap guna pengendalian, namun ialah koordlnasi dan akselerasl untuk segala guna pengendalian administrasi, hingga membuang-buang jam, kekuatan serta bayaran bisa terhindar (Syahril, 2009).

Kedudukan pendidik pada administrasi fasilitas serta pra-sarana diawali rencana, pemanfaatan, serta eksploitasi, dan mengawasi pemakaian fasilitas prasarana. Selaku pelaksana tugas pembelajaran, guru pula memiliki urunan berkepanjangan administrasi fasilitas serta prasarana pembelajaran. Berkepanjangan perihal pendidik banyaknya hubungan deng-an fasilitas pengajar, di mana ialah perlengkapan pengajaran, perlengkapan peraga, serta media pengajaran yang lain, dibanding deng-an keterlibatan pra-sarana pembelajaran tak langsungnya memiliki hubungan.

1. Perencanaan

2. Perencanaan mengadakan benda tuntutan terlibat pendidik sebab seluruh benda gunakan pada berlangsungnya balajaran mengajarkan mesti cocok dengan rancangan aktivitas belajaran mengajarkan. Perencanaan mengadakan benda tuntutan terlibat pendidik antara lain merupakan mengadakan perlengkapan pengajar serta alat pengajar.

3. Pemanfaatan serta Pemeliharaan

4. Guru wajib bisa menggunakan seluruh fasilitas semaksimal dilakukan serta berkewajiban memenuhi selamatan penggunaan fasilitas serta pra-sarana pengajar terdapat.

5. Pengawasan Pemakaian 
Apabila fasilitas serta prasarana pembelajaran itu digunakan oleh siswa yang terdapat dikelasnya, hingga tugas guru ialah melaksanakan pengawasan ataupun membagikan arahan supaya siswa bisa memakai ataupun mengenakan fasilitas serta prasarana pembelajaran itu sebagaimana mestinya.

\section{Simpulan}

Tersedianya fasilitas serta pra-sarana lumayan memiliki andil bagus sangatlah perlukan setiap sekolah manapun penyelenggaraan aktivitas gapai suatu harapkan. Metode yang dipergunakan dalam proses pengumpulan informasi adalah memakai tata cara literatur, dokumentasi, mengenali bermacam masukan, dan data terkini dari internet. Tidak hanya itu, sumber informasi yang dicoba adalah informasi sekunder. Buat pengumpulan data dan informasi mengenakan penulusuran pustaka dan pencarian sumber-sumber relevan melalui internet, dari media elektronik berupa buletin ataupun surat kabar dan dokumen yang lain. Bagi kamus besar Bahasa Indonesia sarana atau fasilitas merupakan seluruh suatu yang bisa dipakai selaku perlengkapan dalam meraih maksud ataupun tujuan. Sebaliknya prasarana merupakan seluruh suatu yang menggambarkan penunjang utama terselenggaranya sesuatu proses (usaha, pembangunan, proyek). Benda-benda pembelajaran supaya tetap siap pada saat digunakan berlangsungnya belajaran mengajarkan hingga efisien serta efektlf menolong tercapainya suatu pembelajaran sudah diresmikan di dalam sekolah. Dengan demikian administrasi pada bidang pendidikan, yakni melakukan usaha buat mengupayakan fasilitas serta perlengkapan peraga yang diperlukan pada proses pendidikan demi lancarnya serta tercapainya tujuan pembelajaran. Perencanaan fasilitas serta prasarana pembelajaran ialah sesuatu berlangsungnya menganalisis serta menetapkan pemenuhan dibutuhkan berlangsungnya pendidikan hingga muncul-lah sebutan pemenuhan dibutuhkan serta pemenuhan mendukung. Saat pengadaan fasilitas serta pra-sarana ter-sebut mesti dicoba rencana dulu. Hal butuh dicermati pada penyusunan rencana fasilitas serta pra-sarana kantor.

Mengadakan seluruh fasilitas serta pra-sarana kantor membutuhkan bayaran besar, dengan tercantum seluruh aktivitas kaitan deng-an pengendaliannya. Inventarisasi fasilitas serta pra-sarana biro merupakan seluruh aktivitas serta usaha buat mendapatkan informasi yang dibutuhkan mengenai fasilitas serta prasarana yang dipunyai. Penyaluran ialah aktivitas tersangkut memindah benda serta berkewajiban lembaga ataupun memegang 1 pada lembaga maupun memegang lainnya. Eksploitasi merupakan aktivitas yang selalu mengusahakan supaya benda ataupun bahan kantor senantiasa dalam kondisi baik ataupun siap buat dipakai. Penghapusan ialah sesuatu proses aktivitas yang bertujuan buat menghasilkan ataupun 
melenyapkan beberapa barang kepunyaan Negeri dari catatan inventaris negeri bersumber pada aturan UU. Segala aktivitas Administrasi Fasilitas serta Prasarana Pembelajaran tidak dapat jalan sendirinya without kendalikan serta awasi, maksudnya tiap aktivitas individu bakal monitoring tiap disaat pemimpin kelompok dan dicermati kerjasama 1 lainnya. Kedudukan pendidik pada administrasi fasilitas serta pra-sarana diawali rencana, pemanfaatan, serta eksploitasi, dan mengawasi pemakaian fasilitas prasarana. Perencanaan mengadakan benda tuntutan terlibat pendidik sebab seluruh benda gunakan pada berlangsungnya balajaran mengajarkan mesti cocok dengan rancangan aktivitas belajaran mengajarkan. Perencanaan mengadakan benda tuntutan terlibat pendidik antara lain merupakan mengadakan perlengkapan pengajar serta alat pengajar. Tersedianya fasilitas serta pra-sarana lumayan memiliki andil bagus sangatlah perlukan setiap sekolah manapun penyelenggaraan aktivitas gapai suatu harapkan.

\section{Saran}

Berikut merupakan sebagian masukan yang penulis bagikan buat arah pertumbuhan berikutnya:

1) Menyatukan faktor-faktor yang ikut serta dalam proses administrasi sarana prasarana pendidikan sekolah supaya berkesinambungan.

2) Ayo kita bersatu membenahi rekomendasi serta prasarana dalam proses sarana prasarna pendidikan yang belum cocok ataupun yang tidak cocok dengan proses pendidikan di sekolah.

3) Pendidikan di sekolah mempraktikkan tata cara yang telah terbukti. 


\section{Referensi}

Afriansyah, H. (2019). Administrasi sarana dan prasarana.

Razak, S. A. (2020). administrasi sarana dan prasarana.

Syahril, D. (2009). Profesi Kependidikan. UNP Press.

Yuliana, Y \& Afriansyah, H. (2019). Administrasi Sarana dan Prasarana. Jurnal Administrasi Sarana Dan Prasarana, 1, 4.

Yahya, (2018). Administrasi dan Supervisi Pendidikan. Padang : unppress. 